\title{
Public health in the European overseas countries and territories: New perspectives for Europe
}

C M Gossner (celine.gossner@ecdc.europa.eu) ${ }^{1}$, T Van Cangh ${ }^{1}$, D Coulombier ${ }^{1}$

1. European Centre for Disease Prevention and Control, Stockholm, Sweden

Citation style for this article:

Gossner CM, Van Cangh T, Coulombier D. Public health in the European overseas countries and territories: New perspectives for Europe.

Euro Surveill. 2011;16(29):pii=19920. Available online: http://www.eurosurveillance.org/ViewArticle.aspx?Articleld=19920

Twenty-five European overseas countries and territories (OCTs) are associated with the European Union (EU) through four Member States of the European Union (EU): Denmark, France, the Netherlands and the United Kingdom. Citizens of OCTs are European citizens, unless they decide to renounce their respective European Member State citizenship. The OCTs are neither part of the EU nor considered as third countries but maintain a special relationship with the EU Member State with which they are constitutionally linked. OCTs should not be confounded with European outermost regions. The European outermost regions have a different legal status from OCTs and constitute an integral part of the EU where Community law is fully applicable [1]. They include the four French overseas departments Guadeloupe, French Guyana, Martinique and La Réunion, the Canary Islands that are part of Spain, and the Azores and Madeira as parts of Portugal.

In this issue of Eurosurveillance, authors from OCTs, the four related EU Member States and the European Centre for Disease Prevention and Control (ECDC) present the results of a study that assesses the needs of the OCTs for preparedness and response to communicable diseases [2]. The study also looks into differences between OCTs and the respective four related EU Member States and among OCTs themselves.

The epidemiological pattern of communicable diseases in the majority of OCTs differs from that in continental Europe. For example, while recurrent epidemics of dengue and chikungunya affect the OCTs respectively in the Caribbean and Pacific regions, and in the Indian Ocean, the European continent is facing the re-emergence of measles [3] and the emergence of multi- and extensively drug-resistant tuberculosis [4].

More than 450,000* European tourists travelled to OCTs in 2009 [5-7]. This large number of tourists and the influx of migrant workers to some OCTs, puts the OCTs at risk to the importation of infectious diseases such as measles that was eliminated from the Caribbean region in 1991 [8]. Reciprocally, the flow of people travelling back from OCTs could potentially introduce and lead to the establishment of infectious diseases that are not endemic in Europe. For instance, in metropolitan France alone, 381 cases of dengue and 46 cases of chikungunya were imported from endemic regions in 2009, with a peak during outbreaks in the French OCTs and outermost regions (overseas departments) [9]. The chikungunya outbreak in Italy in 2007 [10] and more recently the emergence of two cases of autochthonous transmission of dengue virus infection in the south of France [11] have confirmed the risk of introduction and further local transmission of mosquito transmitted viruses to continental Europe, as highlighted by various studies $[12,13]$.

The correlation between the health and wealth of populations has long been established [14]. Beyond decreasing the productivity of affected populations, epidemics in OCTs and the outermost regions are likely to heavily impact tourism, which is a mainstay of many OCTs' economy. For example, as a result of the extraordinary outbreak of chikungunya in La Réunion (French overseas department) in 2005 and 2006, affecting about 300,000 people, tourism on the island dropped by $30 \%$ in 2006 [15]. Taking into account that tourism may represent between one third to half of the gross domestic product in the Dutch and British OCTs in the Caribbean [16], ensuring a 'healthy tourism' is a critical factor for the sustainability of the OCTs' economy which is reliant on tourism.

The detailed rules and procedures of the cooperation between the EU and the OCTs are laid down in the Overseas Association Decision of November 2001 which will expire on 31 December 2013 [17]. In 2008, the Directorate General for Development (DG DEV, since January 2011 DG Development and Cooperation - EuropeAid (DG DEVCO)) initiated a public consultation by launching a Green Paper entitled 'Future relations between the EU and the Overseas Countries and Territories' [18], with a view to review the expiring Overseas Association Decision. The aim of this process is to establish a more reciprocal collaboration and partnership for the benefit of all parties involved.

The European Union should address EU citizens' concerns about public health threats and ensure a high 
level of protection of their health [19]. The same applies to OCT nationals who are also EU citizens. The renewal of the current Overseas Association Decision is thus an opportunity for the EU and its bodies to review the OCTs' public health challenges and particularities and to investigate new possibilities for collaboration on public health matters. There is mutual benefit to cooperate closely and integrate the OCTs more in the prevention and control of communicable diseases at EU level. However, such integration needs to acknowledge the specificities of the OCTs, in terms of epidemiology, ecology, socioeconomic framework and legal status vis-a-vis their related EU Member State.

One possible way to achieve mutual benefit is by strengthening existing regional public health networks and establishing collaboration between these regional networks and the EU in cooperation with the OCT related EU Member States. A body like the European Centre for Disease Prevention and Control (ECDC), established in 2005 to strengthen Europe's defences against infectious diseases [19] could contribute to facilitate this networking by pooling expertise from across the EU, integrating OCTs in a number of its activities or tailor some of its tools and communication platforms to OCTs' particular needs. Should such initiatives reveal an added value in terms of prevention and control of infectious disease outbreaks both for the EU and the OCTs, a more systematic approach towards cooperation in the area of public health could be envisioned. This might, for instance, take the form of an active participation of OCTs in Community programmes in the area of public health or a specific reference to public health cooperation in the future Overseas Association Decision.

\section{Erratum}

* The word 'million' was deleted from this sentence on 31 August 2011.

\section{References}

1. Commission of the European Union. Regional Policy-Inforegio. Regional policy \& outermost regions. Europe's remotest regions. [accessed 2011 May]. Available from: http://ec.europa. eu/regional_policy/activity/outermost/index_en.cfm

2. Jones J, Gastellu-Etchegorry M, Stenz FK, Baudon C, Bloem SJ, Bondonneau M, et al. Epidemiology, surveillance and control of infectious diseases in the European overseas countries and territories, 2011 . Euro Surveill. 2011;16(29): pii=19923. Available from: http://www.eurosurveillance.org/ViewArticle. aspx?Articleld $=19923$

3. European Centre for Disease Prevention and Control (ECDC). European measles monthly monitoring (EMMO), June 2011. Stockholm: ECDC; 2011. Available from: http://ecdc.europa.eu/ en/publications/Publications/2011_June_measles_montly.pdf

4. Devaux I, et al. (2010) Surveillance of extensively drugresistant tuberculosis in Europe, 2003-2007. Euro Surveill. 15(11):pii=19518. Available from: http://www.eurosurveillance. org/images/dynamic/EE/V15N11/art19518.pdf

5. Caribbean Tourism Organization. Individual Country Statistics (2009, 2007, 2006, 2004). 2009. [Accessed 2011 Apr]. Available from: http://www.onecaribbean.org/statistics/ countrystats/.

6. Institut de la statistique de la Polynésie française. Banque de données statistiques, Tourisme, Touristes ayant leur domicile permanent en Europe après 1995. 2009 [accessed 2011 May].
French. Available from: http://www.ispf.pf/ISPF/GdInd/ SerieStat.aspx.

7. Institut de la statistique et des études économiques de la Nouvelle Calédonie. Chiffres clés, tourisme. 2009 [Accessed 2011 May].French. Available from: http://www.isee.nc/ chiffresc/chiffresc.html\#tourisme.

8. Pan American Health Organization. Caribbean Epidemiology Centre, Morbidity Review: Measles and Fever with Rash, in Morbidity Review of Communicable Diseases in CAREC Member Countries, 1980 - 2005. Port of Spain: CAREC; 2008. Available from: http://new.paho.org/carec/dmdocuments/15.\%20 Measles\%20and\%20FR.pdf

9. La Ruche G, Dejour Salamanca D, Debruyne M, Leparc-Goffart I, Ledrans M, Grandadam M, et al. Surveillance par les laboratoires des cas de dengue et de chikungunya importés en France métropolitaine 2008-2009 [Laboratory surveillance of dengue and chikungunya cases imported in metropolitan France 2008-2009]. Bull Epidemiol Hebdo. 2010;(3132):325-9. French. Available from: http://www.invs.sante.fr/ beh/2010/31_32/index.htm

10. Angelini R, Finarelli AC, Angelini P, Po C, Petropulacos K Macini $P$, et al. An outbreak of chikungunya fever in the province of Ravenna, Italy. Euro Surveill. 2007;12(36):pii=3260. Available from: http://www.eurosurveillance.org/ViewArticle. aspx?Articleld $=3260$

11. Ministère du Travail, de l'Emploi et de la Santé. Apparition des premiers cas autochtones de dengue en France métropolitaine [Appearance of the first autochtonous cases of dengue in metropolitan France]. 19 Sep 2010. [Accessed 21 Sep 2010]. French. Available from: http://www.sante-sports.gouv.fr/ apparition-des-premiers-cas-autochtones-de-dengue-enfrance-metropolitaine.html

12. Senior K. Vector-borne diseases threaten Europe. Lancet Infect Dis. 2008;8(9):531-2.

13. Seyler T, Grandesso F, Le Strat Y, Tarantola A, Depoortere E. Assessing the risk of importing dengue and chikungunya viruses to the European Union. Epidemics. 2009;1(3):175-84.

14. Bloom D, Canning D. Epidemics and Economics. Program on the global demography of aging. Working Paper Series; PGDA Working Paper No. 9. Boston: Harvard School of Public Health; 2006.Available from : http://www.hsph.harvard.edu/pgda/ WorkingPapers/2006/BLOOM_CANNINGWP9.2006.pdf).

15. Institut national de la statistique et des etudes economiques. [Internet]. Le bilan économique 2006: Synthèse; Chikungunya; Consommation-Revenus [Economic balance assessment 2006: Synthesis, Chikungunya, consumption-income]: Revue Économie de la Réunion. 2007;2. [French]. Available from: http://www.insee.fr/fr/regions/reunion/default. asp?page $=$ publications/revue/revue_hs.htm

16. Economic Commission for Latin America and the Caribbean. [Internet]. Overseas Countries and Territories: Caught between a rock and a hard place. Trade Negotiations Insights. 2009;3(8). Available from: http://acp-eu-trade.org/library/ files/TNI_EN_8-3.pdf

17. The Council of the European Union. Overseas Association Decision: Official Journal of the European Communities; 30 Nov 2001. L314/1. Available from: http://eur-lex.europa.eu/ LexUriServ/LexUriServ.do?uri=CONSLEG:2001Do822:2007042 6:EN:PDF

18. Commission of the European Communities. Green Paper: Future relations between the EU and the Overseas Countries and Territories. Brussels; Commission of the European Communities; 2008. COM(2008) 383 final. Available from: http://ec.europa.eu/development/icenter/ repository/1 EN ACT part1_v8.pdf

19. The European Parliament and the Council of the European Union, Regulation (EC) No 851/2004 of the European Parliament and of the Council of 21 April 2004 establishing a European centre for disease prevention and control, Official Journal of the European Union. Brussels; 2004. Available from: http://ecdc.europa.eu/en/aboutus/Key\%20Documents/0404_ KD_Regulation_establishing_ECDC.pdf 